\title{
PENGARUH SEMANGAT KERJA, GAYA KEPEMIMPINAN DAN MOTIVASI TERHADAP KINERJA PEGAWAI PADA DINAS PEKERJAAN UMUM DAN PENATAAN RUANG KABUPATEN BARRU
}

\author{
Safirah Syihab ${ }^{1}$, Mashur Razak $^{2}$, Muhammad Hidayat ${ }^{3}$ \\ Program Studi Magister Manajemen PPS STIE NOBEL Indonesia \\ $\underline{\text { naifahnailah@yahoo.co.id }}^{1}, \underline{\text { mashur razak@yahoo.co.id }}^{2} \underline{\text { hidayat2401@yahoo.com }}^{3}$
}

\begin{abstract}
ABSTRAK
Penelitian bertujuan untuk mengetahui dan menganalisis (1) pengaruh semangat kerja, gaya kepemimpinan, dan motivasi kerja terhadap kinerja pegawai Dinas Pekerjaan Umum dan Penataan Ruang Kabupaten Barru (2) variable yang paling dominan berpengaruh terhadap kinerja pegawai.

Populasi dalam penelitian ini adalah seluruh pegawai pada Dinas Pekerjaan Umum dan Penataan Ruang Kabupaten Barru sebanyak 81 orang. Pengambilan sampel penelitian ini dilakukan dengan menggunakan teknik sampling jenuh. Teknik analisa data yang digunakan adalah analisis regresi linier berganda.

Hasil penelitian menunjukkan bahwa (1) terdapat pengaruh semangat kerja, gaya kepemimpinan, dan motivasi kerja terhadap kinerja pegawai Dinas Pekerjaan Umum dan Penataan Ruang Kabupaten Barru. Terdapat pengaruh antara semangat kerja, gaya kepemimpinan dan motivasi secara bersama-sama terhadap kinerja pegawai Dinas Pekerjaan Umum dan Penataan Ruang Kabupaten Barru. (2) motivasi merupakan variabel yang paling dominan berpengaruh terhadap kinerja pegawai Dinas Pekerjaan Umum dan Penataan Ruang Kabupaten Barru.

Kata kunci: semangat kerja, gaya kepemimpinan, motivasi dan kinerja.
\end{abstract}

\section{ABSTRACK}

This research aims to determine and analyze (1) the effect of work morale, leadership style, and work motivation toward the employee performance at the Public Works and Spatial Planning Office in Barru (2) the most dominant variable affects employee performance.

The population was all employees at the Barru District Public Works and Spatial Planning Office as many as 81 people. A sampling of this study was carried out using saturated sampling techniques. The data analysis technique used is multiple linear regression analysis.

The results show that (1) there is an effect of work morale, leadership style, and motivation toward the employee performance at the Public Works and Spatial Planning Office in Barru. There is an effect between work morale, leadership style, and work motivation toward the employee performance at Public Works and Spatial Planning Office in Barru (2) motivation is the most dominant variable affects the employee performance at the Public Works and Spatial Planning Office in Barru.

Keywords: work morale, leadership style, motivation, and performance

\section{PENDAHULUAN \\ Latar Belakang}


Kabupaten Barru adalah salah satu wilayah kabupaten di Sulawesi Selatan yang masuk dalam Pengembangan Kawasan Strategis KEK (Kawasan Ekonomi Khusus). Serta ditunjang dengan hadirnya Pelabuhan Garongkong dan Lintasan Kereta Api Makassar-Parepare, yang mengakibatkan Kabupaten Barru akan berkembang secara ekonomi. Selain pembangunan tersebut diatas banyak mengalami kemajuan namun masih banyak pula yang perlu dibenahi baik kualitas maupun kuantitasnya Pegawai Pemerintah Kabupaten Barru.

Perubahan tersebut juga mengharuskan pegawai untuk mengikuti perubahan. Untuk mengikuti perubahan tersebut, maka organisasi diharapkan agar bisa mengadopsi semua perubahan yang ada secara cepat dan tepat. Tuntutan perubahan tersebut harus diikuti pada perubahan perilaku pegawai diantaranya adalah semangat kerja, gaya kepemimpinan dan motivasi Pegawai Pemerintah Daerah Kabupaten Barru khususnya pada Dinas Pekerjaan Umum dan Penataan Ruang Kabupaten Barru sebagai abdi masyarakat diharapkan agar melakukan setiap perubahan dalam hal melayani masyarakat secara profesional.

Menurut Davis (2011), semangat kerja merupakan sikap emosional yang menyenangkan dan mencintai pekerjaannya. Sikap ini dicerminkan oleh sikap moral kerja, kedisplinan dan prestasi kerja. Dengan semangat kerja yang tinggi, maka kinerja akan meningkat karena pegawai akan bekerja secara lebih tekun sehingga hasil dari pekerjaannya dapat diharapkan lebih cepat dan lebih baik. Begitu juga sebaliknya jika kinerja turun dapat dilihat dari semangat kerja pegawai juga turun. Jadi dengan kata lain kinerja pegawai mempengaruhi semangat kerja pegawai tersebut.

Menurut Nitisemito (2015) pengertian dari semangat kerja adalah keadaan dari dalam diri seseorang yang dapat meningkatkan hasil untuk bekerja lebih cepat dan lebih baik dalam organisasi. Semangat kerja juga merupakan suatu sikap sesorang atau kelompok untuk mencurahkan kemampuannya dalam kesukarelaan untuk bekerjasama. Menurut Winardi (2011) semangat kerja juga dapat diartikan perasaan senang, ketiadaan konflik, penyesuaian pribadi secara baik, dan tingkat keterlibatan ego dalam melakukan kegiatan. Siagian (2010) menyatakan bahwa semangat kerja dapat dilihat dari kegairahan pegawai dalam mengerjakan tugas serta bertanggung jawab didalam organisasi.

Pada Dinas Pekerjaan Umum dan Penataan Ruang Kabupaten Barru sesuai dengan tuntutan perubahan yang ada masih perlu untuk meningkatkan kesiapan perilaku pegawai peningkatan tersebut perlu diprioritaskan pada permasalahan semangat kerja yang masih menjadi masalah prioritas dalam meningkatkan produktivitas kerja.

Selain hal tersebut kepemimpinan juga menjadi salah satu faktor keberhasilan penyiapan organisasi dalam menghadapi perubahan untuk itu sangat dibutuhkan kepemimpinan yang efektif pada suatu organisasi agar mampu menunjukkan prestasinya. Kepemimpinan adalah ujung tanduk untuk perkembangan organisasi, karena tanpa kepemimpinan yang tepat akan sulit untuk mengembangkan organisasi.

Adapun definisi dan pengertian kepemimpinan menurut para ahli, pendapat Kartono (2008), gaya kepemimpinan adalah kepribadian, sifat, watak, kebiasaan, dan tempramen yang berbeda-beda dalam berinteraksi antara pimpinan dan bawahannya. Pendapat Supardo (2006), gaya kepemimpinan adalah suatu proses dan cara kompleks yang digunakan untuk mencapai suatu tujuan, sasaran dan misi dalam mengarahkan organisasi melalui cara yang tepat untuk mempengaruhi orang lain. Pendapat Rivai (2014), gaya kepemimpinan adalah sekelompok ciri yang dipilih pimpinan untuk 
mempengaruhi orang lain agar tujuan dan sasaran organisasi dapat dicapai atau dapat pula dikatakan bahwa gaya kepemimpinan adalah cara perilaku dan strategi seorang pimpinan yang sering digunakan dan disukai. Pendapat Hasibuan (2014), gaya kepemimpinan adalah suatu cara agar organisasi dapat mencapai tujuan dengan pemimpin yang berusaha agar bawahannya terpengaruh dan mau bekerja sama secara produktif. Pendapat Thoha (2010), gaya kepemimpinan merupakan norma perilaku yang diterapkan oleh seorang pemimpin pada saat mempengaruhi perilaku bawahan ataupu orang lain.

Kinerja organisasi akan meningkat dengan gaya kepemimpinan yang tepat. Kepemimpinan adalah proses mempengaruhi dalam menentukan tujuan organisasi, memotivasi perilaku pengikut untuk mencapai tujuan, untuk mempengaruhi dan memperbaiki kelompok dan budayanya.

Demi tercapainya tujuan pada Dinas Pekerjaan Umum dan Penataan Ruang Kabupaten Barru, pegawai memerlukan motivasi untuk bekerja lebih rajin. Melihat pentingnya pegawai, maka diperlukan perhatian pegawai lebih serius terhadap tugas yang dikerjakan sehingga tujuan organisasi tercapai. Dengan motivasi yang tinggi, pegawai akan bekerja lebih giat didalam melaksanakan pekerjaannya. Sebaliknya dengan motivasi yang rendah pegawai tidak mempunyai semangat bekerja, mudah menyerah, dan kesulitan dalam meyelesaikan pekerjaannya. Motivasi akan muncul apabila manusia sudah merasa dipenuhi segala kebutuhannya.

Sesuai dengan pendapat Daft (2012), mengungkapkan bahwa motivasi (motivation) mengarah kepada keinginan, dalam memunculkan kegigihan antusiasme baik dari luar dan dalam diri seseorang untuk mengerjakan suatu pekerjaan. Sedangkan Ivancevich (2012), menyatakan bahwa motivasi merupakan kemauan dan dorongan yang kuat dari seorang individu untuk mengubah perilakunya agar tujuan tercapai. Gibson et.al, (2010), motivasi adalah dasar mengarahkan dan memulai perilaku yang dipakai untuk memaparkan suatu kekuatan yang ada pada atau sekitar pribadi. Motivasi yang dimaksud adalah keinginan dan dorongan yang kuat untuk merubah perilaku dari seorang individu.

Sedangkan Winardi (2011), menjabarkan bahwa motivasi adalah kemauan dari dalam diri seorang individu untuk melakukan pekerjaan secara terpaksa. Motivasi merupakan fungsi dari berbagai macam variabel yang saling mempengaruhi, ia merupakan suatu proses yang terjadi dalam diri manusia atau suatu proses psikologis.

Kekuatan motivasi pegawai untuk bekerja dan menghasilkan kinerja secara langsung tercermin sebagai upayanya seberapa jauh ia bekerja keras. Upaya ini mungkin menghasilkan kinerja yang baik.

Adapun pendapat dari para ahli tentang kinerja, yaitu menurut Gibson (2010), kinerja merupakan hasil kerja seseorang sesuai dengan tanggung jawab dan hasil yang diharapkan. Tujuan organisasi dapat tercapai jika kinerja pegawai dalam melaksanakan pekerjaannya telah berhasil dan sesuai dengan tugasnya masing-masing.

Menurut Lijan Poltak Sinambela, dkk (2015) mengemukakan bahwa kinerja pegawai didefinisikan sebagai kemampuan pegawai dalam melakukan sesuatu keahlian tertentu. Kinerja pegawai sangatlah perlu, sebab dengan kinerja ini akan diketahui seberapa jauh kemampuan pegawai dalam melaksanakan tugas yang dibebankan kepadanya. Untuk itu diperlukan penentuan kriteria yang jelas dan terukur serta ditetapkan secara bersama-sama yang dijadikan sebagai acuan. 
Selanjutnya, untuk meningkatkan kinerja Pegawai Dinas Pekerjaan Umum dan Penataan Ruang Kabupaten Barru yang belum optimal yang disebabkan rendahnya semangat kerja dan motivasi. Hal ini dapat dilihat dari ada sikap kurang harmonis antar sesama pegawai, kurangnya kerjasama dan rasa kepedulian yang kurang. Rasa persaingan yang tinggi dari masing-masing pegawai untuk menambah keahlian, baik yang didapat dari segi pelatihan dan pendidikan maupun dari segi akademis. Yang sangat dibutuhkan pada Dinas Pekerjaan Umum dan Penataan Ruang Kabupaten Barru adalah kerjasama tim yang kuat dalam suatu kesatuan. Apabila hal ini dibiarkan berkelanjutan dan tidak dicarikan jalan keluar akan berakibat buruk bagi Dinas Pekerjaan Umum dan Penataan Ruang Kabupaten Barru di masa yang akan datang.

Hal ini diperkuat dengan peneliti terdahuluYulianti (2018), Pengaruh Gaya Kepemimpinan dan Motivasi Terhadap Kinerja Karyawan CV. CIPTA NUSA Sidoarjo, Gaya Kepemimpinan dan Motivasi secara simultan berpengaruh terhadap kinerja karyawan. Ini juga sejalan dengan Bonita (2014), Pengaruh Motivasi dan Semangat Kerja Terhadap Kinerja Pegawai Dinas Perkebunan Kabupaten Indragiri Hilir. Penelitian dilakukan pada Dinas Perkebunan Kabupaten Indragiri Hilir, dengan hasil Hasil penelitian membuktikan bahwa, 1) Motivasi $\left(\mathrm{X}_{1}\right)$ dan Semangat Kerja $\left(\mathrm{X}_{2}\right)$ secara simultan atau bersama-sama berpengaruh secara signifikan terhadap kinerja pegawai perkebunan di Dinas Perkebunan Indragiri Hilir, 2) Motivasi $\left(\mathrm{X}_{1}\right)$ secara parsial berpengaruh positif dan signifikan terhadap kinerja pegawai perkebunan di Dinas Perkebunan Indragiri Hilir dan 3) Motivasi merupakan variabel yang paling dominan pengaruhnya terhadap kinerja pegawai Dinas Perkebunan Kabupaten Indragiri Hilir.

Berdasarkan latar belakang masalah tersebut diatas, maka pokok-pokok permasalahan dalam penelitian ini adalah sebagai berikut 1) Apakah semangat kerja, gaya kepemimpinan dan motivasi berpengaruh secara parsial terhadap kinerja pegawai pada Dinas Pekerjaan Umum dan Penataan Ruang Kabupaten Barru? 2) Apakah semangat kerja, gaya kepemimpinan dan motivasi berpengaruh secara simultan terhadap kinerja pegawai pada Dinas Pekerjaan Umum dan Penataan Ruang Kabupaten Barru? 3) Variabel manakah yang paling dominan berpengaruh terhadap kinerja pegawai pada Dinas Pekerjaan Umum dan Penataan Ruang Kabupaten Barru?

Penelitian ini bertujuan untuk mengetahui dan menganalisis, 1) Pengaruh semangat kerja, gaya kepemimpinan dan motivasi berpengaruh secara parsial terhadap kinerja pegawai pada Dinas Pekerjaan Umum dan Penataan Ruang Kabupaten Barru. 2) Pengaruh semangat kerja, gaya kepemimpinan dan motivasi berpengaruh secara simultan terhadap kinerja pegawai pada Dinas Pekerjaan Umum dan Penataan Ruang Kabupaten Barru. 3) Variabel yang paling dominan berpengaruh terhadap kinerja pegawai pada Dinas Pekerjaan Umum dan Penataan Ruang Kabupaten Barru.

\section{KERANGKA TEORI Semangat Kerja}

Kualitas sumber daya manusia (SDM) sangat mempengaruhi keberhasilan dalam organisasi hal ini dapat dilihat dari tercapainya visi dan misi secara berkesinambungan pada kualitas suatu organisasi. Suatu organisasi bisnis ataupun publik harus menjadi learning organization, jika ingin tetap konsisten dan mempertahankan organisasinya. Kualitas sumber daya manusia (SDM) sangat mempengaruhi keberhasilan dalam

Menurut Nitisemito (2015) pengertian dari semangat kerja adalah keadaan dari dalam diri seseorang yang dapat meningkatkan hasil untuk bekerja lebih cepat dan lebih 
baik dalam organisasi. Semangat kerja juga merupakan suatu sikap sesorang atau kelompok untuk mencurahkan kemampuannya dalam kesukarelaan untuk bekerjasama.

Menurut Nitisemito (2015, Laksarini 2018), indikator-indikator semangat kerja adalah sebagai berikut, 1) Produktivitas kerja, 2) Tingkat kehadiran, 3) Ketenangan dalam bekerja.

\section{Gaya Kepemimpinan}

Gaya kepemimpinan adalah cara, model, dan kemampuan tertentu seorang pemimpin untuk mempengaruhi, mengarahkan, mendorong, dan mengendalikan orang lain atau bawahan agar dapat mencapai tujuan mereka dalam perilaku, komunikasi, dan interaksi. Gaya kepemimpinan adalah strategi dan perilaku untuk meningkatkan kinerja bawahan dari hasil perpaduan sifat, sikap, sifat, keterampilan dan falsafah, yang digunakan seorang pemimpin. Gaya kepemimpinan menggambarkan cara pemimpin baik langsung ataupun tidak langsung untuk meyakinkan bawahan terhadap kemampuan pimpinan.

Gaya kepemimpian yang digunakan seorang pemimpin dengan pemimpin lainnya berbeda, dan tidak bisa dibandingkan-bandingkan baik buruknya antara gaya kepemimpinan yang satu dengan gaya kepemimpinan lain.

Pendapat Kartono (2008, Alfia 2016), indikator gaya kepemimpinan dapat dinilai dan dinilai dari beberapa hal sebagai berikut, (a) kemampuan mengambil keputusan, (b) kemampuan memotivasi, (c) kemampuan komunikasi.

\section{Motivasi}

Berbagai istilah digunakan untuk menyebut kata motivasi (motivation) atau motif, antara lain kebutuhan (need), desakan (urge), keinginan (wish), dan dorongan (drive).

Motivasi memiliki peranan yang penting bagi seorang pegawai, tinggi atau rendahnya motivasi pegawai memiliki dampak terhadap perkembangan organisasi. Bila pegawai termotivasi, organisasi akan memiliki kemugkinan yang besar untuk mencapai sasarannya.

Di tempat kerja, motivasi merupakan salah satu faktor penting dalam mendorong seseorang karyawan untuk bekerja. Ada tiga elemen kunci dalam motivasi yaitu kebutuhan organisasi, usaha, dan tujuan organisasi. Usaha adalah ukuran kekuatan. Jika seseorang termotivasi, ia akan melakukan segala usaha untuk mencapai tujuan, tetapi itu tidak selalu membutuhkan banyak usaha untuk menghasilkan kinerja tinggi.

Kekuatan motivasi tenaga kerja untuk bekerja/berkinerja secara langsung tercermin sebagai upayanya seberapa jauh ia bekerja keras. Upaya ini mungkin menghasilkan kinerja yang baik atau sebaliknya, karena ada dua faktor yang harus benar jika upaya itu akan diubah menjadi kinerja. Pertama, pegawai harus memiliki kemampuan yang diperlukan untuk mengerjakan tugasnya dengan baik. Tanpa kemampuan dan upaya yang tinggi, tidak mungkin menghasilkan kinerja yang baik. Kedua adalah persepsi pegawai yang bersangkutan tentang bagaimana upayanya dapat diubah sebaik-baiknya menjadi kinerja, diasumsikan bahwa persepsi tersebut dipelajari dari pengalaman sebelumnya pada situasi yang sama. (ejurnal.unp.ac.id,2016).

Menurut Hamzah B. Uno (2012, Yulianti 2018) dimensi dan indikator motivasi dapat dikelompokkan sebagai berikut, (1) Motivasi Internal, terdiri dari tanggung jawab dalam melaksanakan tugas dan melaksanakan tugas dengan target yang jelas, (2) 


\section{AkMen}

motivasi eksternal terdiri dari senang memperoleh pujian dari apa yang dikerjakannya dan bekerja dengan harapan ingin memperoleh perhatian dari teman dan atasan.

\section{Kinerja}

Kinerja merupakan hasil kerja secara kualitas dan kuantitas yang dicapai oleh seorang pegawai dalam melaksanakan tugasnya sesuai dengan tanggung jawab yang diberikan kepadanya. Kinerja pegawai sangatlah perlu, sebab dengan kinerja ini akan diketahui seberapa jauh kemampuan pegawai dalam melaksanakan tugas yang dibebankan kepadanya. Untuk itu diperlukan penentuan kriteria yang jelas dan terukur serta ditetapkan secara bersama-sama yang dijadikan sebagai acuan.

Menurut Rivai (2014) bahwa kinerja adalah hasil atau tingkat keberhasilan seseorang atau keseluruhan selama periode tertentu didalam melaksanakan tugas dibandingkan dengan berbagai kemungkinan, seperti standar hasil kerja, target atau sasaran atau kriteria yang telah ditentukan terlebih dahulu dan telah disepakati bersama.

Menurut Emron (2016), menekankan pada waktu penyelesaian produk, sedangkan menurut pemikiran John Miner menekankan indikator waktu terhadap kehadiran pegawai. Maka dapat disimpulkan menjadi, (a) target, (b) kualitas, (c) waktu penyelesaian, dan $(\mathrm{d})$ taat asas.

\section{Kerangka Konseptual}

Gambar 1 mengilustrasikan model penelitian dan hibungan antar variable yang digunakan dalam penelitian ini. Variabel bebas adalah semangat kerja, gaya kepemimpinan dan motivasi dengan variable terikatnya adalah kinerja pegawai.

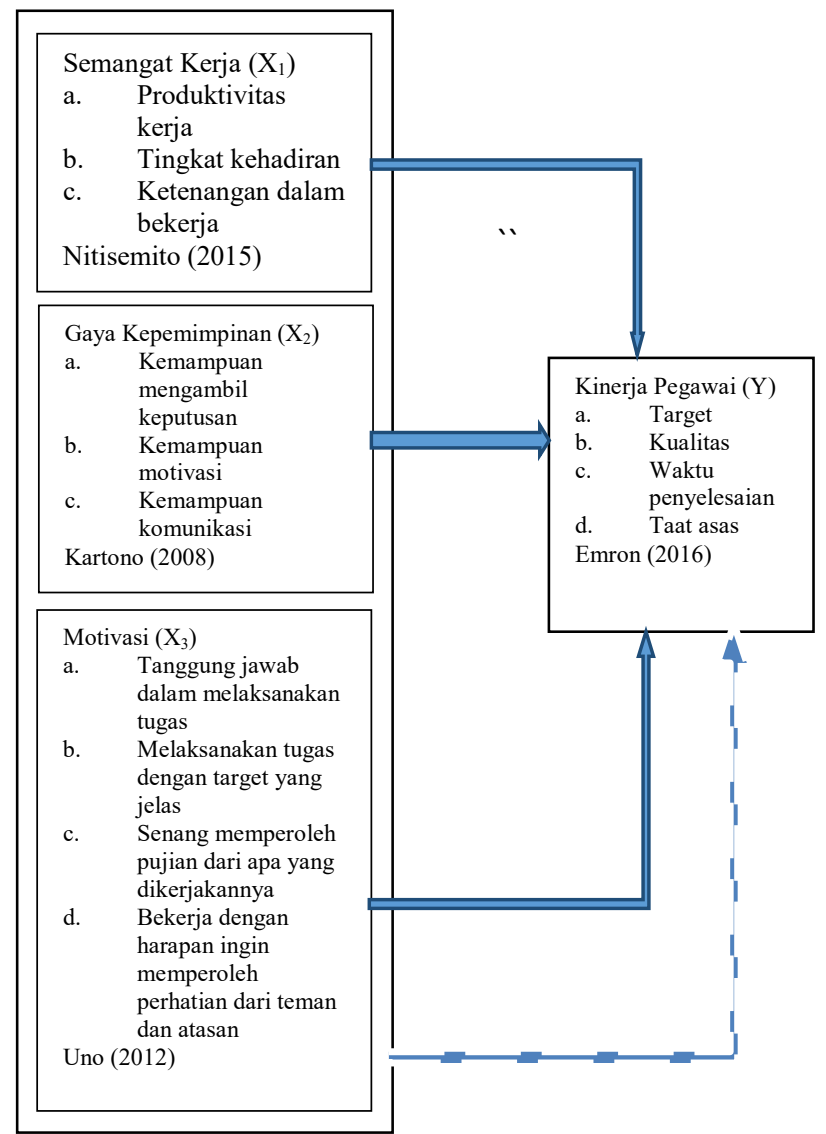


Gambar 1. Kerangka Konseptual

\section{Hipotesis Penelitian}

Berdasarkan uraian diatas dapat disusun hipotesis sebagai berikut, semangat kerja, gaya kepemimpinan dan motivasi perpengaruh positif dan signifikan secara parsial terhadap kinerja pegawai pada Dinas Pekerjaan Umum dan Penataan Ruang Kabupaten Barru. Semangat kerja, gaya kepemimpinan dan motivasi perpengaruh positif dan signifikan secara simultan terhadap kinerja pegawai pada Dinas Pekerjaan Umum dan Penataan Ruang Kabupaten Barru. Dan Variabel motivasi yang paling dominan berpengaruh terhadap kinerja pegawai pada Dinas Pekerjaan Umum dan Penataan Ruang Kabupaten Barru.

\section{METODE PENELITIAN}

Waktu penelitian mulai bulan September 2019 sampai dengan November 2019. Pemilihan sampel dalam penelitian ini dilakukan dengan menggunakan metode sampling jenuh (sensus) yakni dengan menentukan semua populasi sebagai sampel total sebanyak 81 orang. Teknik yang digunakan untuk mengumpulkan data dalam penelitiann ini adalah daftar pertanyaan (kuesioner) dan studi dokumentasi. Peneliti memberikan lima alternatif jawaban kepada responden dengan menggunakan skala 1 sampai dengan 5 untuk keperluan analisis kuantitatif penelitian. Kesimpulan penelitian yang berupa jawaban permasalahan penelitian, dibuat berdasarkan hasil proses pengujian data yang meliputi: pemilihan, pengumpulan dan analisis data. Dengan menggunakan program SPSS.

Instrumen penelitian terdiri dari, Uji Validitas dan Realibilitas, Uji Asumsi Dasar, terdiri dari Uji Homogenitas, Uji Linearitas, dan Uji Normalitas, dan Uji Asumsi Klasik terdiri dari Uji Autokorelasi, Uji Heteroskedastisitas, Uji Multikolinearitas, dan Uji Normalitas Regresi.

Teknik analisis data kuantitatif yang diperoleh dari hasil kuesioner dengan menggunakan analisis regresi berganda (multiple regression analysis). Kemudian untuk mengetahui pengaruh semangat kerja $\left(\mathrm{X}_{1}\right)$, gaya kepempinan $\left(\mathrm{X}_{2}\right)$, dan motivasi $\left(\mathrm{X}_{3}\right)$, terhadapa variabel terkait yaitu kinerja pegawai $(\mathrm{Y})$, secara parsial maka dilakukan uji t.

Selanjutnya untuk mengetahui pengaruh variabel bebas yaitu: semangat kerja ( $\left.\mathrm{X}_{1}\right)$, gaya kepempinan $\left(\mathrm{X}_{2}\right)$, dan motivasi $\left(\mathrm{X}_{3}\right)$, terhadapa variabel terkait yaitu kinerja pegawai (Y), secara bersama-sama, maka dilakukan uji F.

\section{HASIL DAN PEMBAHASAN}

Dari uji validitas yang dilakukan terhadap skor setiap item variabel bebas dan variabel terikat menunjukkan sahih, dengan nilai Corrected Item Total Correlation positif di atas 0,2185 . Tingkat keterkaitan antar item pertanyaan dalam suatu instrumen untuk mengukur Variabel tertentu menunjukkan tingkat reliabilitas konsistensi internal instrumen yang bersangkutan dengan nilai Cronbach's Alpha diatas 0,6. Hasil Uji heteroskedastisitas tidak menunjukkan gambaran suatu pola yang sama dan terbentuk suatu garis lurus atau biasa dikatakan homokedastik, maka persamaan regresi ini disebut mempunyai heterokedastisitas. Hasil VIF dari variabel bebas yang masing-masing mempunyai nilai diantara 1 (satu) sampai dengan 10 (sepuluh), hal ini menyatakan bahwa tidak ada gejala multikolinearitas. 


\section{AkMen}

\section{Uji Analisis Regresi Linear Berganda}

Dengan menggunakan alat bantu program analisa data SPSS maka diperoleh nilai koefisien regresi masing-masing variable, dapat diliat pada tabel 2:

\begin{tabular}{|c|c|c|c|c|c|}
\hline \multicolumn{6}{|c|}{ Coefficients $^{\mathrm{a}}$} \\
\hline \multirow{2}{*}{ Model } & \multicolumn{2}{|c|}{$\begin{array}{l}\text { Unstandardized } \\
\text { Coefficients }\end{array}$} & \multirow{2}{*}{$\begin{array}{c}\text { Standardized } \\
\text { Coefficients } \\
\text { Beta }\end{array}$} & \multirow[t]{2}{*}{$\mathrm{t}$} & \multirow[t]{2}{*}{ Sig. } \\
\hline & $\mathrm{B}$ & Std. Error & & & \\
\hline $\begin{array}{ll}1 & \text { (Constant) }\end{array}$ & 1.993 & 1.567 & & 1.272 & .207 \\
\hline Semangat Kerja (X1) & .260 & .104 & .223 & 2.503 & .014 \\
\hline Gaya Kepemimpinan (X2) & .285 & .092 & .289 & 3.102 & .003 \\
\hline Motivasi (X3) & .491 & .111 & .405 & 4.421 & .000 \\
\hline
\end{tabular}

Tabel 2 Hasil perhitungan regresi

Maka persamaan regresinya menjadi: $\quad \mathrm{Y}=1,993+0,260 \mathrm{X}_{1}+0,285 \mathrm{X}_{2}+0,491 \mathrm{X}_{3}$

Formulasi regresi linear berganda di atas diperoleh nilai konstanta sebesar 1,993. Nilai koefisien regresi semangat kerja $\left(\mathrm{X}_{1}\right)$ sebesar 0,260 berarti ada pengaruh positif semangat kerja terhadap kinerja pegawai. Nilai koefisien regresi gaya kepemimpinan $\left(\mathrm{X}_{2}\right)$ sebesar 0,285 berarti ada pengaruh positif gaya kepemimpinan terhadap kinerja pegawai. Nilai koefisien regresi motivasi $\left(\mathrm{X}_{3}\right)$ sebesar 0,491 berarti ada pengaruh positif motivasi terhadap kinerja pegawai

Dari uraian uji $t$ dengan menggunakan program analisa data SPSS maka diketahui bahwa variabel bebas/independen semangat kerja $\left(\mathrm{X}_{1}\right)$, gaya kepemimpinan $\left(\mathrm{X}_{2}\right)$, dan motivasi $\left(\mathrm{X}_{3}\right)$ berpengaruh terhadap kinerja pegawai Dinas Pekerjaan Umum dan Penataan Ruang Kabupaten Barru. Variabel semangat kerja $\left(\mathrm{X}_{1}\right)$ dengan nilai $t_{\text {hitung }}$ $2,503>\mathrm{t}_{\text {tabel }} 1,6648$, variabel gaya kepemimpinan $\left(\mathrm{X}_{2}\right)$ dengan nilai $\mathrm{t}_{\text {hitung }} 3,102>\mathrm{t}_{\text {tabel }}$ 1,6648 , dan variabel motivasi $\left(\mathrm{X}_{3}\right)$ dengan nilai $\mathrm{t}_{\text {hitung }} 4,421>\mathrm{t}$ tabel 1,6648 .

Karena nilai $F_{\text {hitung }}$ sebesar 33,747, dapat diliat pada tabel 3, berarti variabel bebas/independen $(\mathrm{X})$ yang meliputi semangat kerja, gaya kepemimpinan dan motivasi secara simultan berpengaruh terhadap kinerja pegawai Dinas Pekerjaan Umum dan Penataan Ruang Kabupaten Barru bisa dikatakan signifikan karena dari pengujian menunjukkan bahwa hasil $\mathrm{F}_{\text {hitung }}=33,747$ lebih besar dari $\mathrm{F}$ tabel $=2,72$ atau bisa dikatakan $\mathrm{H}_{\mathrm{o}}$ ditolak dan $\mathrm{H}_{\mathrm{a}}$ diterima. 


\section{AkMen \\ Volume 17 Nomor 2 Juni 2020 \\ Hal.194-204 \\ e-ISSN : 2621-4377 \& p-ISSN : 1829-8524 \\ Hbmepage: https//e-jurnal.stienobel-indonesia.acid/index.php/akmen}

ANOVA $^{\mathrm{a}}$

\begin{tabular}{|rl|r|r|r|r|r|}
\hline \multicolumn{1}{|c|}{ Model } & \multicolumn{1}{c|}{$\begin{array}{c}\text { Sum of } \\
\text { Squares }\end{array}$} & df & Mean Square & F & Sig. \\
\hline $1 \quad$ Regression & 149.534 & 3 & 49.845 & 33.741 & $.000^{\circ}$ \\
& & & & & \\
& Residual & 113.750 & 77 & 1.477 & & \\
Total & 263.284 & 80 & & & \\
\hline
\end{tabular}

Tabel 3 Hasil Uji F

Berdasarkan hasil nilai beta standardized diketahui bahwa variabel-variabel yang meliputi semangat kerja, gaya kepemimpinan dan motivasi maka yang mempunyai pengaruh yang paling besar terhadap kinerja pegawai Dinas Pekerjaan Umum dan Penataan Ruang Kabupaten Barru adalah variabel motivasi $\left(\mathrm{X}_{3}\right)$ dengan nilai 0,419.

Nilai koefisien determinasi (R square) sebesar 0,568 yang dapat diartikan bahwa variabel bebas/independen $(\mathrm{X})$ yang meliputi semangat kerja, gaya kepemimpinan dan motivasi mempunyai kontribusi terhadap kinerja pegawai Dinas Pekerjaan Umum dan Penataan Ruang Kabupaten Barru sebesar 56,8\%, sedangkan sisanya sebesar 43,2\% dipengaruhi oleh variabel lain yang tidak termasuk dalam penelitian ini.

\section{SIMPULAN DAN SARAN \\ Simpulan}

Adapun beberapa kesimpulan yang dapat ditarik dari hasil penelitian ini yaitu, terdapat pengaruh semangat kerja terhadap kinerja pegawai Dinas Pekerjaan Umum dan Penataan Ruang Kabupaten Barru, dengan nilai $\mathrm{t}_{\text {hitung }} 2,503>\mathrm{t}_{\text {tabel }} 1,6648$, terdapat pengaruh gaya kepemimpinan terhadap kinerja pegawai Dinas Pekerjaan Umum dan Penataan Ruang Kabupaten Barru, dengan nilai $\mathrm{t}_{\text {hitung }} 3,102>\mathrm{t}$ tabel 1,6648, terdapat pengaruh motivasi terhadap kinerja pegawai Dinas Pekerjaan Umum dan Penataan Ruang Kabupaten Barru, nilai $t_{\text {hitung }} 4,421>t_{\text {tabel }} 1,6648$, terdapat pengaruh antara semangat kerja, gaya kepemimpinan dan motivasi secara bersama-sama terhadap kinerja pegawai Dinas Pekerjaan Umum dan Penataan Ruang Kabupaten Barru, dari pengujian menunjukkan bahwa hasil $\mathrm{F}_{\text {hitung }}=33,741$ lebih besar dari $\mathrm{F}$ tabel $=2,72$ atau bisa dikatakan $\mathrm{H}_{\mathrm{o}}$ ditolak dan $\mathrm{H}_{\mathrm{a}}$ diterima. Variabel motivasi yang paling dominan berpengaruh terhadap kinerja pegawai Dinas Pekerjaan Umum dan Penataan Ruang Kabupaten Barru, berdasarkan hasil nilai beta standardized yang paling besar yaitu 0,491 .

\section{Saran}

Untuk menjadi bahan perbaikan kinerja pegawai Dinas Pekerjaan Umum dan Penataan Ruang Kabupaten Barru, yaitu bagi organisasi, penelitian ini diharapkan dapat dijadikan sebagai informasi atau masukan dalam peningkatan kinerja pegawai berdasarkan variabel semangat kerja dan motivasi yang dimiliki pegawai dan gaya kepemimpinan yang dimiliki oleh pemimpin. Selanjutnya yang perlu diperhatikan agar dapat meningkatkan kinerja pegawai melalui gaya kepemimpinanan adalah memberikan komitmen layanan pengetahuan kepada para pegawai tentang sistem kerja, budaya kerja, beban kerja, dan standar kerja sehingga meskipun ada perubahan dalam sistem 
kerja dan metode kerja, pegawai terus memahami tugas pokok dan fungsi jabatan yang didudukinya Bagi pihak akademis dapat dijadikan bahan rujukan bagi peneliti-peneliti selanjutnya yang variabelnya berkenaan dengan semangat kerja, gaya kepemimpinan dan motivasi serta kinerja pegawai. Bagi peneliti sebagai motivasi agar dapat terus dapat mengembangkan dirinya untuk peningkatan sumber daya manusia.

\section{DAFTAR PUSTAKA}

Nitisemito Alex S., 2014, Manajemen Personalia, Galia Indonesia, Jakarta.

Yulianti Arini (2018), Pengaruh Gaya Kepemimpinan dan Motivasi Terhadap Kinerja Karyawan CV. CIPTA NUSA Sidoarjo.

Bonita Aswin (2014), Pengaruh Motivasi dan Semangat Kerja Terhadap Kinerja Pegawai Dinas Perkebunan Kabupaten Indragiri Hilir.

Hamzah, B Uno, 2012, Teori Motivasi dan Pengukurannya, PT. Bumi Aksara, Jakarta.

Carlaw, Deming, \& Friedman (2008), Managing and Motivatiting Contact Center Employees, Mc. Graw Hill Publishing Company, Singapore.

Daft, Richart L., 2012, The Leadeship Experiens, Thomson, Canada.

Davis, 2011, Perilaku dalam Organisasi, Buku I, penerjemah: Dharma Agus, Penerbit Erlangga, Jakarta.

Edison, Emron, Yohny Anwar, Imas Komariyah (2016), Manajemen Sumber Daya Manusia, Alfabeta, Bandung.

Ejurnal.unp.c.id, 2016

Gibson, James. L, et LL, 2010, Organisasi, Perilaku, Struktur, Proses, Edisi Ke-5, Erlangga, Jakarta.

Hasibuan, Malayu. 2014. Manajemen Sumber Daya Manusia. Jakarta: Bumi Aksara.

Ivancevich, John M. and Lee Soo Hoon, 2012, Human Resource Management in Asia, McGrawe-Hill, Singapore.

Kartono, Kartini. 2008. Pemimpin dan Kepemimpinan. Jakarta: Raja Grafindo Persada.

Alfia, Layli (2016), Pengaruh Gaya Kepemimpinan dan Semnagat Kerja Terhadap kinerja Pegawai (Studi Kasus pada Kantor Kecamatan Ciputat Timur).

Laksarini, Riayana Fitri (2018), Pengaruh Semnagat Kerja Terhadap Kinerja Karyawan Non Medis di Rumah Sakit Islam Siti Aisyah Madiun. 

AkMen
Volume 17 Nomor 2 Juni 2020
Hal.194-204
e-ISSN : 2621-4377 \& p-ISSN : 1829-8524
Homepage: https//e-jurnal.stiendbel-indonesia.acid/index.php/akmen

Rivai, Z., Veithzal, dkk. 2014. Kepemimpinan dan Perilaku Organisasi. Jakarta: Raja Grafindo Persada.

Supardo, Susilo. 2006. Kepemimpinan, Dasar-dasar dan Pengembangannya. Yogyakarta: Andi offset.

Sinambela, Lijam Poltak, 2016, Manajemen Sumber Daya Manusia, PT. Bumi Aksara, Jakarta.

Sondang, Siagian, 2010, Manajemen Sumber Daya Manusia, Bumi Aksara, Jakarta.

Thoha, Miftah, 2010. Kepemimpinan dalam Manajemen, Rajawali Pers, Jakarta.

Winardi, 2011, Kepemimpinan dalam Manajemen, PT. Rineka Cipta, Jakarta. 